\title{
Gea
}

JURNAL PENDIDIKAN GEOGRAFI

\section{ANALISIS PEMANFAATAN LAHAN UNTUK PENGEMBANGAN BAHAN AJAR IPS (Studi Kasus pada Materi Pelestarian Lingkungan Hidup di SMP Kecamatan Argapura Kabupaten Majalengka)}

\author{
Enok Yanti \\ SMP Negeri 4 Maja, Kab. Majalengka, email: yanticioray@yahoo.co.id
}

\begin{abstract}
The research aims at analyzing the land use by farmers, identifying the causes, knowing the relationship of the students' understanding with their attitudes, and formulating materials about using of land on environmental preservation materials. The method is descriptive analytic. Data were collected through field surveys, interviews, literature studies and documentation. The population includes farmers, eighth grade students and MTs teachers in Argapura District. Farmer samples were randomly stratified, learners were taken using a proportional random sampling and teacher samples were the whole population. Data were analyzed using percentages and simple and multiple linear regression. The results show that the land use in the Argapura District was largely incompatible with the slope and the frequency of attending counseling as a causative factor of land use has a negative significance level. Students' understanding of the land condition is parallel with their attitude towards land use so learning materials should be suited to the conditions of their environment to produce meaningful learning. It is recommended that the land use follow the environmental land management rules to preserve the environment, and existing materials were only concepts. Therefore further research should be on land use materials on environmental preservation materials in Class VIII Semester 1.
\end{abstract}

Keywords: Land use, teaching materials, preservation of the environment.

\section{PENDAHULUAN}

Berdasarkan kebijakan pola tata ruang Propinsi Jawa Barat dan Kabupaten Majalengka " luas kawasan lindung sebesar 40,76\%, saat ini tinggal $15,85 \%$ dari luas wilayah Kabupaten Majalengka" (Bappeda, 2011:34). Keberadaan kawasan lindung yang saat ini tinggal $15,85 \%$ dari luas wilayah Kabupaten Majalengka, hal tersebut menyebabkan perlunya pelestarian kawasan-kawasan lainnya yang dapat diberi fungsi lindung. Sementara itu, hutan produksi dan lahan-lahan di lereng pegunungan saat ini oleh masyarakat sekitar telah dijadikan menjadi lahan budidaya berupa areal perkebunan dan palawija/hortikultura.

Sebagian wilayah di Kecamatan Argapura Kabupaten Majalengka awalnya berstatus sebagai kawasan hutan lindung dan hutan produksi, sedangkan sekarang sebagian wilayah tersebut berstatus kawasan Taman Nasional Gunung Ciremai (TNGC). Status kawasan hutan lindung Gunung Ciremai mengalami perubahan menjadi Taman Nasional Gunung Ciremai (TNGC) berdasarkan Keputusan Menteri Kehutanan R.I nomor SK 424/menhutII/2004 tanggal 19 Oktober 2004 tentang perubahan status hutan lindung menjadi kawasan Taman Nasional Gunung Ciremai, dengan luas $\pm 15.500 \mathrm{Ha}$ yang terletak di Kabupaten Majalengka dan Kuningan dan yang masuk dalam wilayah Kabupaten Majalengka seluas 6.933,13Ha (5,76 \%) dari total luas wilayah Kabupaten Majalengka (Kurung dan Ginanjar, 2012:8). Kawasan Taman Nasional Gunung Ciremai (TNGC) yang terletak di Kecamatan Argapura Kabupaten Majalengka yaitu Argalingga, Cikaracak, Gunung Wangi, Mekarwangi, Argamukti, dan Tejamulya. 
Berubahnya status kawasan hutan lindung dan hutan produksi menjadi Taman Nasional Gunung Ciremai (TNGC) di sebagian wilayah Kecamatan Argapura menimbulkan masalah bagi petani di daerah tersebut. Wilayah Taman Nasional Gunung Ciremai (TNGC) menurut peraturan tidak boleh diganggu maupun dimanfaatkan oleh masyarakat sekitar sedangkan dahulu masyarakat sekitar banyak memanfaatkan wilayah hutan produksi dengan cara bercocok tanam dengan cara tumpang sari. Berubahnya status kawasan tersebut dan semakin bertambahnya jumlah penduduk sehingga terjadi peningkatan aktivitas ekonomi di Kecamatan Argapura, hal tersebut menyebabkan masyarakat petani turun gunung dan akhirnya memanfaatkan lahan mereka meskipun tidak layak untuk diolah sebagai lahan pertanian. Banyak lahan dengan kemiringan curam yang seharusnya digunakan untuk tanaman tahunan atau kayu-kayuan tetapi dimanfaatkan oleh petani sebagai tanaman semusim/ hortikultura dengan tidak mengindahkan kelestarian lingkungan.

Sebagian wilayah Kecamatan Argapura merupakan perbukitan dengan lereng yang curam dan terletak di kaki Gunung Ciremai. Kondisi topografis ini selain sangat berpengaruh pada pemanfaatan ruang dan potensi pengembangan wilayah, juga mengakibatkan terdapatnya daerah rawan longsor khususnya daerah yang mempunyai lereng yang curam. Menurut survei awal ternyata sebagian wilayah Kecamatan Argapura merupakan daerah rawan longsor dan sebagian mempunyai lahan kritis, hal ini disebabkan oleh perlakuan masyarakat petani dalam mengolah lahan yang tidak mengindahkan kaidah kelestarian lingkungan. Perlakuan tersebut misalnya lahan diolah terus menerus tanpa ada jeda dalam penanaman tiap tahunnya dan belum menggunakan teknik konservasi yang baik.

Berdasarkan pemaparan di atas, perlu adanya peningkatan kesadaran dan pemahaman masyarakat khususnya di daerah yang mempunyai kemiringan lereng sangat curam akan pentingnya kawasan lindung sebagai kawasan konservasi yang akan memberikan kelangsungan hidup masyarakat Majalengka di masa yang akan datang. Peningkatan kesadaran dan pemahaman masyarakat bisa melalui pendidikan geografi dengan cara menelaah kembali bahan ajar Geografi di SMP tentang pelestarian Lingkungan Hidup sehingga generasi penerus bangsa dalam hal ini peserta didik bisa menerapkan pengetahuan geografi di lapangan kelak ketika mereka terjun di masyarakat. Hal tersebut disebabkan karena tidak menutup kemungkinan peserta didik yang berada di Kecamatan Argapura ada yang mengikuti jejak orang tuanya sebagai pengolah lahan. Meskipun peserta didik ada yang tidak mengikuti orang tuanya sebagai pengolah lahan, minimal mereka bisa berinteraksi dengan orang tuanya yang sebagian besar bermata pencaharian sebagai petani untuk bisa mengelola lahan dengan arif sehingga kelestarian lingkungan bisa terjaga.

Berdasarkan pengamatan awal terhadap kurikulum 2006 (KTSP) khususnya pada bahan ajar yang dipergunakan oleh guru ternyata pemanfaatan lahan belum terdapat dalam materi usaha pelestarian lingkungan. Bahan ajar yang selama ini terdapat pada perangkat pembelajaran hanya mencakup unsur biotik/abiotik, kelestarian lingkungan di daerah sungai ataupun laut. Begitu juga dengan kondisi peserta didik di Kecamatan Argapura, ratarata mereka belum memahami bagaimana pemanfaatan lahan yang sesuai dengan kaidah penggunaan lahan dalam kaitannya dengan kelestarian lingkungan hidup. Bahan ajar yang ingin penulis kembangkan yaitu konsep bahan ajar yang bersifat kontekstual dengan cara menambahkan indikator yang sudah ada sehingga pemanfaatan lahan masuk ke dalam bahan ajar geografi tersebut dan akhirnya tercipta pembelajaran kontekstual antara materi dengan keadaan sesungguhnya sehingga 
akan menumbuhkan kebermaknaan dalam pembelajaran.

Berdasarkan latar Belakang di atas, dirumuskan permasalahan yang akan diteliti yaitu bagaimanakah pemanfaatan lahan di Kecamatan Argapura oleh masyarakat petani setempat, Faktor-faktor apa saja yang menyebabkan pemanfaatan lahan oleh masyarakat petani setempat, Bagaimanakah hubungan pemahaman dengan sikap peserta didik terhadap pemanfaatan lahan di lingkungan sekitar mereka, dan Bagaimanakah pengembangan bahan ajar IPS di SMP berkaitan dengan pemanfaatan lahan pada materi pelestarian lingkungan hidup.

Berdasarkan rumusan masalah yang telah diuraikan di atas, maka tujuan penelitian ini untuk mengidentifikasi pemanfaatan lahan oleh masyarakat petani Kecamatan Argapura berkenaan dengan pelestarian lingkungan hidup, mengidentifikasi faktor-faktor penyebab pemanfaatan lahan di Kecamatan Argapura oleh masyarakat petani setempat, mengidentifikasi hubungan pemahaman dengan peserta didik tentang pemanfaatan lahan di sekitar lingkungan mereka dan merumuskan bahan ajar IPS yang bisa dikembangkan untuk materi pelestarian lingkungan hidup pada jenjang SMP.

Secara teoritis, manfaat penelitian ini diharapkan dapat memberikan sumbangan bagi pengembangan materi tentang pemanfaatan lahan yang bisa dimasukkan ke dalam bahan ajar IPS pada materi Pelestarian Lingkungan Hidup semester 1 kelas VIII pada jenjang SMP dan sebagai masukan data untuk penelitian selanjutnya mengenai pemanfaatan lahan dalam kaitannya dengan pengembangan bahan ajar IPS Geogerafi. Sedangkan secara praktis, penelitian ini diharapkan bermanfaat bagi pendidik untuk meningkatkan pembelajaran IPS dengan menggunakan bahan ajar yang dibuat sesuai kondisi lingkungan sekitar atau kontekstual sehingga penggunaan bahan ajar tidak terpaku pada bahan ajar yang sudah ada dari buku atau penerbit, bermanfaat bagi peserta didik sehingga mereka memahami tentang pemanfaatan lahan yang bijak terhadap kelestarian lingkungan di sekitar mereka, dan sebagai bahan masukan bagi lembaga/instansi terkait dalam hal pengelolaan lahan sehingga dalam pertimbangannya dapat diambil keputusan yang sesuai terutama bagi para pembuat kebijakan yang hendak membangun wilayah yang bersangkutan.

\section{METODE PENELITIAN}

Metode penelitian yang digunakan adalah metode deskriptif analitik. Menurut Surakhmad (1982:12) "metode deskriptif analitik adalah penyelidikan deskriptif yang tertuju pada suatu cara untuk memecahkan suatu masalah yang ada sekarang diantaranya menuturkan dan menafsirkan data yang ada, mengklasifikasikan, disusun, dijelaskan dan dianalisis". Adapun Jenis penelitian yang digunakan adalah penelitian survei. Menurut Singarimbun, M (1995 : 3) "penelitian survei adalah penelitian yang mengambil sampel dari satu populasi dan menggunakan kuesioner sebagai alat pengumpulan data yang pokok". Penelitian survei dilakukan untuk memperoleh data mengenai pemanfaatan lahan yang dilakukan masyarakat petani dan data terkait lainnya juga untuk memperoleh data dari peserta didik mengenai pemahaman pemanfaatan lahan pada proses pembelajaran pelestarian lingkungan hidup.

Menurut Arikunto, S (1992:102) "populasi adalah keseluruhan subyek penelitian". Sedangkan "sampel adalah sebagian atau wakil dari populasi" (Arikunto, 1992: 104). Populasi dalam penelitian ini adalah seluruh Kepala Keluarga Tani di wilayah Kecamatan Argapura terdiri atas pemilik, penggarap, pemilik penggarap serta buruh tani dan seluruh peserta didik kelas VIII SMP maupun MTs yang terdapat di Kecamatan Argapura beserta semua guru IPS yang terdapat di SMP dan MTs tersebut. 
Metode pengambilan sampel penelitian adalah proportional random sampling dengan membuat proporsi masing-masing jumlah sampel sesuai dengan jumlah peserta didik kelas VIII yang ada di SMP dan MTs tersebut sedangkan khusus untuk populasi guru IPS Geografi sampelnya diambil semua berdasarkan populasi.

Pengambilan sampel kepala keluarga tani dilakukan melalui dua tahap, pertama pengambilan sampel wilayah dan yang kedua pengambilan sampel kepala keluar- ga tani berdasarkan status kepemilikan lahan. Pengambilan sampel wilayah dilakukan dengan cara mengelompokkan wilayah tersebut berdasarkan kecenderungan petani dalam melakukan pola tanam dan jenis tanaman. Teknik pengambilan sampel petani secara acak (stratified random sampling) berdasarkan kepemilikan lahan yaitu sebagai pemilik, penggarap, pemilik penggarap dan buruh tani. Jumlah masing-masing populasi dan sampel disajikan pada Tabel 1 dan Tabel 2.

Tabel 1. Populasi dan Sampel Peserta Didik dan Guru

\begin{tabular}{rrrrrr}
\hline \multirow{2}{*}{ No. } & Nama Sekolah & \multicolumn{2}{c}{ Populasi } & \multicolumn{2}{c}{ Sampel } \\
\cline { 3 - 6 } & & $\begin{array}{c}\text { Peserta } \\
\text { didik }\end{array}$ & Guru & $\begin{array}{c}\text { Peserta } \\
\text { didik }\end{array}$ & Guru \\
\hline 1. & SMPN Argapura 1 & 145 & 2 & 50 & 2 \\
\hline 2. & SMPN Argapura 2 & 58 & 3 & 20 & 3 \\
\hline 3. & SMPN Argapura 3 & 45 & 4 & 16 & 4 \\
\hline 4. & MTs Almudzakirin & 47 & 1 & 16 & 1 \\
\hline & Jumlah & $\mathbf{2 9 5}$ & $\mathbf{1 0}$ & $\mathbf{1 0 2}$ & $\mathbf{1 0}$ \\
\hline
\end{tabular}

Sumber : Hasil perhitungan, 2013

Tabel 2. Populasi dan Sampel Petani

\begin{tabular}{crrrrrrrrrr}
\hline \multirow{2}{*}{ Desa } & \multicolumn{2}{c}{ Pemilik } & \multicolumn{2}{c}{ Penggarap } & \multicolumn{2}{c}{ Pemilik-penggarap } & \multicolumn{2}{c}{ Buruh tani } & \multicolumn{2}{c}{ Jumlah total } \\
\cline { 2 - 14 } & Populasi & Sampel & Populasi & Sampel & Populasi & Sampel & Populasi & Sampel & Populasi & Sampel \\
\hline Argalingga & 23 & 5 & 9 & 2 & 146 & 33 & 13 & 3 & 191 & 43 \\
\hline Sikasari & 37 & 8 & 13 & 3 & 53 & 12 & 13 & 3 & 116 & 26 \\
\hline Tejamulya & 37 & 8 & 26 & 6 & 101 & 23 & 9 & 2 & 173 & 39 \\
\hline Mekarwangi & 17 & 4 & 9 & 2 & 13 & 3 & 17 & 4 & 56 & 13 \\
\hline Jumlah & $\mathbf{1 1 4}$ & $\mathbf{2 5}$ & $\mathbf{5 7}$ & $\mathbf{1 3}$ & $\mathbf{3 1 3}$ & $\mathbf{7 1}$ & $\mathbf{5 2}$ & $\mathbf{1 2}$ & $\mathbf{5 3 6}$ & $\mathbf{1 2 1}$ \\
\hline
\end{tabular}

Sumber : Hasil perhitungan, 2013

Langkah-langkah untuk menganalisis data penelitian ini adalah sebagai berikut : Langkah pertama menggunakan penskoran. Penskoran hasil instrumen kuesioner dalam penelitian ini menggunakan skala likert dengan bentuk cheklist. Langkah kedua dalam menganalisis yaitu melakukan persentase. Langkah ketiga untuk menganalisis penyebab pemanfaatan lahan dipergunakan regresi linier dengan cara menggandengkan variabel $(x)$ dengan variabel (y). Faktor-faktor yang mempengaruhi pemanfaatan lahan yaitu tingkat pendidikan (X1), luas kepemilikan lahan (X2), status kepemilikan lahan (X3), penyuluhan (X4) dan tingkat pendapatan (X5). Regresi linear yang dipakai adalah regresi sederhana dan regresi linear ganda.
Dari grafik regresi diperoleh persamaan garis regresi, yaitu:

Regresi linear sederhana :

$\mathrm{Y}=\mathrm{a}+\mathrm{bx}$

Regresi linear Ganda :

$\mathrm{Y}=\mathrm{a}+\mathrm{bx}_{1}+\mathrm{bx}_{2}+\ldots . .+\mathrm{bx}$

Keterangan $: Y=$ variabel dependen

$\mathrm{X}, \mathrm{X} 1, \mathrm{Xn}=$ variabel independen

$\mathrm{a}=$ konstanta;

$\mathrm{b}=$ koefisien regresi

\section{HASIL DAN PEMBAHASAN \\ Pemanfaatan Lahan oleh Masyarakat}

Penggunaan Lahan (land use) adalah suatu proses yang dinamis dan sebagai hasil dari perubahan pada pola dan besarnya aktivitas manusia sepanjang waktu, dan merupakan masalah yang bersifat kompleks (Lasaiba, 1:2013) 
sedangkan pemanfaatan lahan dapat diartikan sebagai apa yang dilakukan masyarakat saat ini terhadap lahan.

Pemanfaatan lahan di Kecamatan Argapura mempunyai dua kriteria yaitu pemanfaatan lahan sesuai dan pemanfaatan lahan yang tidak sesuai. Penentuan kriteria sesuai atau tidak sesuai suatu pemanfaatan lahan dalam penelitian ini berdasarkan hasil overlay peta kemiringan lereng dengan peta pemanfaatan lahan aktual yang terdapat di Kecamatan Argapura. Kemudian peta hasil tumpang susun tersebut dianalisis berdasarkan kelas kemiringan lereng (kelas kemiringan lereng 1 sampai dengan kelas kemiringan lereng VI).

Berdasarkan Tabel 3, pemanfaatan lahan yang sesuai seluas 6.114 ha $(71,83 \%)$ dengan pemanfaatan lahan didominasi hutan seluas $1.942,88$ ha $(22,88 \%)$, kemudian pemanfaatan lahan yang sesuai lainnya yaitu padang rumput seluas 16,64 ha $(0,20 \%)$, sawah irigasi seluas 169,24 ha $(1,99 \%)$, tanah berbatu seluas 14,21 ha $(0,17 \%)$ dan waterfill seluas 11,31 ha $(0,13 \%)$.

Tabel 3

Pemanfaatan Lahan Sesuai dan Tidak Sesuai

\begin{tabular}{|c|c|c|c|c|c|c|}
\hline No & $\begin{array}{c}\text { Jenis Pemanfaatan } \\
\text { Lahan }\end{array}$ & $\begin{array}{l}\text { Sesuai } \\
\text { ( ha) }\end{array}$ & $\%$ & $\begin{array}{c}\text { Tidak } \\
\text { sesuai } \\
\text { (ha) }\end{array}$ & $\%$ & $\begin{array}{c}\text { Jumlah } \\
\text { (ha) }\end{array}$ \\
\hline 1 & Pemukiman & 46,63 & 0,55 & 235,52 & 2,77 & 282,15 \\
\hline 2 & Ladang & $1.264,49$ & 14,85 & 1330,25 & 15,63 & $2.594,74$ \\
\hline 3 & Padang rumput & 16,64 & 0,20 & - & - & 16,64 \\
\hline 4 & Sawah irigasi & 169,24 & 1,99 & - & - & 169,24 \\
\hline 5 & Sawah tadah hujan & 638,12 & 7,50 & 354,48 & 4,16 & 992,60 \\
\hline 6 & Semak belukar & $1.879,77$ & 22,08 & 360,61 & 4,24 & $2.240,38$ \\
\hline 7 & Perkebunan & 130,71 & 1,54 & 117,47 & 1,38 & 248,18 \\
\hline 8 & Tanah berbatu & 14,21 & 0,17 & - & - & 14,21 \\
\hline 9 & Hutan & $1.942,88$ & 22,82 & - & - & $1.942,88$ \\
\hline 10 & Waterfill & 11,31 & 0,13 & - & - & 11,31 \\
\hline & Jumlah (ha) & 6.114 & 71,83 & $2.398,33$ & 28,17 & $8.512,33$ \\
\hline
\end{tabular}

Sedangkan pemanfaatan lahan yang tidak sesuai seluas $2.398,33$ ha $(28,17 \%)$ didominasi oleh pemanfaatan lahan ladang seluas $1.330,25$ ha $(15,63 \%)$. Pemanfaatan lahan yang tidak sesuai lainnya terdiri atas pemukiman seluas 235,52 ha $(2,77 \%)$, sawah tadah hujan seluas 354,48 ha $(4,16 \%)$, semak belukar seluas 360,61 ha $(4,24 \%)$ dan perkebunan 117,47 ha $(1,38 \%)$. Komposisi pemanfaatan lahan yang sesuai maupun tidak sesuai berdasarkan kemiringan lereng untuk lebih jelas disajikan pada Gambar 1. 


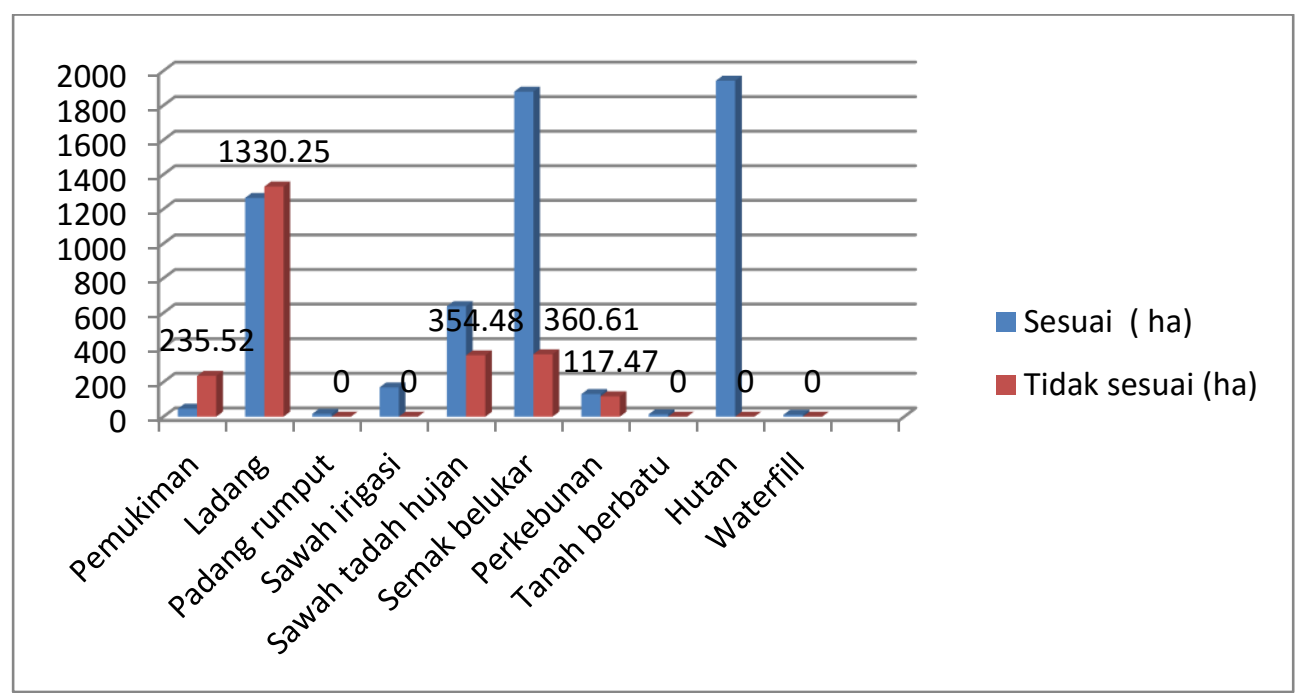

Gambar 1. Grafik Kriteria Pemanfaatan Lahan

Gambar 1, menunjukkan pemanfaatan lahan untuk ladang merupakan lahan yang mempunyai kriteria tidak sesuai lebih besar dibandingkan ladang yang sesuai. Pemanfaatan lahan ladang yang tidak sesuai seluas $1.330,25$ ha $(15,63 \%)$ sedangkan ladang yang sesuai hanya $1.264,49$ ha $(14,85 \%)$. Pemanfaatan lahan untuk ladang yang tidak sesuai dengan prosentase paling luas di antara pemanfaatan lahan yang tidak sesuai lainnya disebabkan oleh lokasi pemanfaatan lahan pada kemiringan lereng yang curam sampai sangat curam yaitu $25 \%$ - > $40 \%$.

Pemanfaatan lahan yang kurang sesuai dan kurang bijak dalam pengelolaannya bisa menyebabkan degradasi lahan. Degradasi lahan bisa disebabkan salah satunya yaitu oleh erosi dan longsor. Sedangkan erosi ataupun longsor salah satu pemicunya yaitu kemiringan lereng yang curam, faktor curah hujan yang tinggi, tekstur tanah, batuan induk dan biasanya diperparah oleh karena ulah manusia yang tidak bijak dalam mengelola lahannya. Demikian juga di Kecamatan Argapura, pemanfaatan lahan untuk ladang justru lebih banyak yang tidak sesuainya dibandingkan yang sesuai karena beberapa faktor yaitu curah hujan cukup tinggi, kemiringan lereng curam sampai sangat curam, tutupan lahan yang kurang sesuai dan diperparah oleh perlakuan masyarakat terhadap lahan kurang bijak. Perlakuan masyarakat petani yang kurang bijak misalnya memanfaatkan lahan untuk ladang dengan tanaman semusim/hortikultura di lereng curam sampai sangat curam, pengolahan lahan tanpa jeda dalam tiap musim tanam dan penerapan konservasi yang kurang layak. Ketika perlakuan masyarakat petani terhadap lahan kurang bijak maka dapat dipastikan bahwa kelestarian lingkungan hidup akan terganggu.

\section{Faktor-faktor Penyebab Pemanfaatan Lahan oleh Masyarakat Petani}

"Jalur tengah Pulau Jawa yang terbentuk oleh sistem gunungapi strato dicirikan oleh tingkat kelerengan curam karena pengaruh stuktur geologi, serta curah hujan yang relatif tinggi sehingga laju pelapukan juga intensif" (Purnomo, N.H, 1: 2013). Kondisi tersebut menjadikan wilayah demikian memiliki tingkat kesuburan yang tinggi juga merupakan daerah rawan bencana sama seperti yang terjadi di Kecamatan Argapura. Berkaitan dengan pemanfaatan lahan, masyarakat petani kecamatan Argapura sebagian sudah mengetahui bahwa Kecamatan Argapura merupakan daerah yang rentan gerakan tanah dan longsor tetapi mereka masih mengolah lahan dengan kurang bijak di wilayah tersebut.

Berdasarkan hasil pengolahan data dan survei di lapangan, ternyata faktor yang signifikan mempengaruhi pemanfaat- 
an lahan oleh masyarakat setempat terdiri atas frekuensi mengikuti penyuluhan, tingkat pendapatan petani, dan luas kepemilikan lahan. Frekuensi mengikuti penyuluhan dan tingkat pendapatan petani memiliki taraf signifikansi negatif sedangkan luas kepemilikan lahan mempunyai signifikansi positif.

Terdapat fenomena yang menarik yaitu faktor frekuensi mengikuti penyuluhan merupakan faktor yang signifikan dari seluruh pengujian antara pemahaman dan sikap terhadap pemanfaatan lahan pada empat kelompok masyarakat. Tetapi frekuensi mengikuti penyuluhan mempunyai taraf signifikansi negatif. Frekuensi mengikuti penyuluhan mempunyai signifikansi negatif artinya bahwa semakin intensif petani mengikuti penyuluhan semakin tidak positif pemahaman dan sikap terhadap pemanfaatan lahan di daerah Argapura yang rawan bencana erosi dan longsor tersebut. Hal tersebut disebabkan oleh materi penyuluhan kepada para petani hanya membahas cara menghasilkan produksi yang melimpah sehingga permintaan pasar terpenuhi tanpa membahas sedikitpun informasi tentang daerah mereka merupakan daerah rawan bencana erosi dan longsor. Hal demikian diperparah lagi bahwa masyarakat petani yang intensif mengikuti penyuluhan pertanian adalah mereka yang tergabung ke dalam kelompok tani. Kelompok tani yang terdapat di kecamatan Argapura merupakan kelompok tani yang melakukan kerja sama dengan pihak luar (investor) seperti dengan Amarta dari Amerika di bawah naungan FAO ( PBB), Singapura, PT Indofood dan pengusaha-pengusaha sayuran skala besar di daerah lampung, Jakarta, Bogor dan Bandung (pasar Caringin dan pasar Ciroyom) sebagai pemasok sayuran. Kerjasama dengan Amarta di bawah naungan FAO (PBB) meliputi wilayah Cibunut, Argalingga, Tejamulya dan Sukadana sebagai sentra cabe. Kerjasama dengan PT Indofood yaitu Argalingga sebagai pemasok kentang untuk produk chitato, untuk Singapur dipasok baby cabbage, tomat, wortel tomat dan kol. Pengusaha sayur di Jakarta dan Bogor meminta pasokan bawang daun dan bawang merah. Sedangkan untuk Lampung, dan Bandung Kecamatan Argapura sebagai pengirim kol, tomat, wortel, pecai dan bawang daun. Atas anjuran dari penyuluh pertanian kelompok tani tersebut selalu dituntut untuk meningkatkan hasil produksi sayuran supaya kerja sama dengan pihak yang bersangkutan tidak terputus. Sehingga dapat dibayangkan bahwa lahan yang mereka manfaatkan untuk tanaman semusim terus diforsir bahkan banyak yang mengolah lahan tanpa jeda dalam penanamannya. Dapat disimpulkan bahwa penyuluhan pertanian mempunyai pengaruh yang luar biasa terhadap pemahaman dan sikap petani dalam memanfaatkan lahan. Penyuluhan pertanian selayaknya berbasis konservasi supaya lahan bisa terawat dan kelestarian lingkungan akhirnya bisa terjaga.

Kemudian tingkat pendapatan petani dari beberapa hasil pengujian juga mempunyai taraf signifikansi negatif. Artinya semakin tinggi pendapatan petani ternyata semakin tidak positif pemahaman dan sikap mereka terhadap pemanfaatan lahan. Misal petani yang mempunyai pendapatan $>20 \mathrm{jt} / 4$ bulan mereka lebih mendahulukan membeli perhiasan, alat elektronik bahkan membeli kendaraan bermotor dibandingkan untuk biaya perawatan lahan. Tetapi ketika hasil panen mereka turun atau mengalami kerugian pada masapanen berikutnya, mereka menjual kembali perhiasan ataupun kendaraan bermotor untuk dipergunakan sebagai modal. Begitu seterusnya dari masa tanam satu ke masa tanam lainnya.

Faktor penyebab pemanfaatan lahan lainnya yaitu luas kepemilikan lahan. Luas kepemilikan lahan berdasarkan beberapa hasil pengujian terhadap empat kelompok masyarakat petani mempunyai signifikansi positif, artinya bahwa semakin luas kepemilikan lahan mereka maka semakin 
positif pemahaman dan sikap mereka terhadap pemanfaatan lahan. Petani yang memiliki lahan yang luas meskipun mereka tidak sadar bahwa daerah mereka rawan bencana erosi maupun longsor, tetapi mereka melaksanakan konservasi. Hal tersebut dilakukan karena turun temurun dari orang tua mereka atau bahkan hanya ikut-ikutan dari orang lain yang melaksanakan konservasi. Sedangkan petani yang memiliki lahan yang relatif sempit mereka tidak melaksanakan konservasi dengan alasan bahwa konervasi akan mengurangi luas lahan garapan mereka dan juga memerlukan biaya yang tidak sedikit. Begitu juga mereka yang mempunyai luas lahan garapan relatif sempit merasa keberatan kalau pada lahan mereka diselingi degan tanaman tahunan karena mereka mempunyai alasan selain bisa mengurangi luas lahan garapan, penanaman tanaman tahunan juga lama untuk mendatangkan hasil.

Selanjutnya tingkat pendidikan meskipun mempunyai korelasi yang positif terhadap pemahaman tetapi kurang signifikan terhadap pemahaman dan sikap dalam pemanfaatan lahan. Hubungan tingkat pendidikan dengan pemahaman ternyata mempunyai korelasi positif, artinya semakin tinggi tingkat pendidikan petani semakin positif pula pemahaman petani terhadap pemanfaatan lahan. Pemahaman yang positif tersebut ternyata tidak disertai dengan sikap yang positif terhadap pemanfaatan lahan. Sebagai contoh, petani yang memiliki pendidikan tinggi mempunyai pemahaman yang bagus terhadap kondisi lahan yang rentan erosi dan longsor tetapi sikap mereka tidak mendukung dalam hal pemanfaatan lahan yang bijak karena mereka hanya berstatus sebagai penggarap atau bahkan sebagai buruh tani dan mereka rata-rata tidak mempunyai pekerjaan lain selain sebagai petani. Sehingga dapat ditarik kesimpulan bahwa proses pendidikan selayaknya bukan hanya transfer ilmu pengetahuan sehingga mereka paham terhadap kondisi lingkungan tetapi tidak bersikap bijak dalam mengelola lingkungan. Serta tidak kalah penting bahwa materi pembelajaran harus kontekstual sehingga bisa bermakna dan bisa diaplikasikan dalam kehidupan sehari-hari.

\section{Hubungan Pemahaman dengan Sikap Peserta Didik terhadap Pemanfaatan Lahan di Lingkungan Sekitar Mereka}

Berdasarkan hasil pengujian regresi antara pemahaman dengan sikap peserta didik terhadap pemanfaatan lahan diperoleh nilai $\mathrm{R}=0,032$. Nilai $\mathrm{R}$ tersebut menandakan bahwa hubungan antara variabel pemahaman dengan persepsi peserta didik sangat rendah karena nilai $R$ semakin mendekati nilai 0 . Kemudian nilai koefisien determinasi $\mathrm{R}$ (square) sebesar $0,001(0,032 \times 0,032=0,001)$, angka ini menunjukkan bahwa sikap atau persepsi peserta didik terhadap pemanfaatan lahan dipengaruhi sebesar $0,1 \%$ dari pemahaman peserta didik tentang pemanfaatan lahan. Sedangkan sisanya yaitu 9,9\% ( $100 \%-0,1$ $\%=9,9 \%$ ) dijelaskan oleh sebab lain.

Jika dilihat dari linearitasnya pada uji Anova, maka diperoleh $F$ hitung sebesar 0,106 sedangkan nilai $X$ kritik atau $F$ tabel sebesar 0,746 dengan signifikansi $5 \%$ atau 0,05 . Karena F hitung $<$ F tabel $(0,106<$ 0,746 ), artinya tidak ada pengaruh secara signifikan antara pemahaman dengan sikap peserta didik terhadap pemanfaatan lahan. Selanjutnya dilakukan uji coefficient atau uji beta untuk melihat seberapa besar pengaruh yang dimiliki oleh kedua variabel. Nilai konstan yang diperoleh sebesar 19,984, nilai B untuk pemahaman 0.033 , nilai $t_{\text {hitung }} 7,156$ dan tingkat signifikansi 0,000 sehingga didapat persamaan regresi sederhana yaitu $Y=a+b x ; Y=19,984+0,033 x$.

Persamaan tersebut menunjukkan tidak adanya perbandingan lurus yang signifikan dari aspek pemahaman terhadap sikap peserta didik dalam pemanfaatan lahan, apabila pemahaman peserta didik meningkat 1 satuan, maka aspek sikap mereka dalam pemanfaatan lahan akan 
tetap. Artinya dapat dikatakan bahwa tidak ada pengaruh yang dimiliki antara pemahaman dengan sikap peserta didik dalam pemanfaatan lahan.

\section{Pengembangan Bahan Ajar IPS Geografi} di SMP Berkaitan dengan Pemanfaatan Lahan pada Materi Pelestarian Lingkungan Hidup

Bahan ajar yang dipergunakan selama ini merupakan bahan ajar yang tidak kontekstual dengan kehidupan sehari-hari khususnya di Kecamatan Argapura karena pendidik atau guru menggunakan bahan ajar yang masih konvensional yaitu bahan ajar yang langsung pakai, atau membeli dari penerbit, instan dan biasanya tanpa usaha merencanakan, menyiapkan, dan menyusunnya sendiri. Hal tersebut menyebabkan bahan ajar yang dipakai oleh guru tidak kontekstual, tidak menarik, monoton dan bahkan bisa jadi kurang sesuai dengan kebutuhan peserta didik. Karena itu, seorang guru dituntut kreatifitasnya untuk menyusun bahan ajar sendiri dan disesuaikan dengan kebutuhan peserta didik.

Pengembangan bahan ajar IPS Geografi pada SMP berkaitan dengan pemanfaatan lahan pada materi pelestarian pelestarian lingkungan hidup dilakukan beberapa tahapan. Tahapan tersebut diklasifikasikan menjadi tiga tahapan penting yaitu (1) analisis kebutuhan bahan ajar, (2) menyusun peta bahan ajar, dan (3) menyusun bahan ajar berdasarkan struktur masing-masing bentuk bahan ajar. Berikut tahapan dalam pengembangan bahan ajar geografi untuk SMP berkaitan dengan pemanfaatan lahan.

Tahapan pertama dalam pengembangan bahan ajar yaitu menganalis bahan ajar. Pada tahap menganalisis bahan ajar terdiri atas beberapa kegiatan menganalisis kurikulum, menganalisis sumber belajar, dan memilih serta menentukan bahan ajar. Menganalisis kurikulum dengan cara mengidentifikasi standar kompetensi, kompetensi dasar, indikator ketercapaian hasil belajar dan terakhir menganalisis materi pokok. Menganalisis sumber belajar dilakukan berdasarkan ketersediaan, kesesuaian, dan kemudahan dalam memanfaatkannya. Memilih bahan ajar tentunya dilakukan supaya bahan ajar menarik dan bisa membantu peserta didik untuk mencapai kompetensi. Pada tahap menganalisis kurikulum ini dilakukan dengan cara mengkaji Standar Kompetensi (SK) dan Kompetensi Dasar (KD) yang terdapat pada standar isi (SI). Hasil analisis SK dan KD dijadikan dasar untuk penentuan isi bahan ajar tentang pemanfaatan lahan pada materi pelestarian lingkungan hidup yang akan dikembangkan. Matriks analisis kurikulum tentang pemanfaatan lahan disajikan pada Tabel 4. Berdasarkan analisis kebutuhan bahan ajar tersebut, penulis berusaha membuat bahan ajar tentang pemanfaatan lahan pada materi pelestarian lingkungan hidup diharapkan dengan tersusunnya bahan ajar tersebut dapat meningkatkan kepedulian peserta didik terhadap lingkungan hidup.

Tahap kedua dalam pengembangan bahan ajar yaitu memahami Kriteria Pemilihan Sumber Belajar. Pada tahap ini dilakukan penyeleksian atau pemilihan terhadap sumber belajar. Pemilihan sumber belajar berdasarkan pertimbangan kesesuaian dengan tujuan pembelajaran yang telah ditentukan sebelumnya pada matriks analisis kurikulum. Banyak sumber belajar yang bisa dijadikan untuk pembuatan bahan ajar. Menurut Prastowo (2012: 34) "Sumber belajar dibedakan menjadi lima macam, yaitu tempat atau lingkungan alam sekitar, benda, orang, buku, peristiwa, dan fakta yang sedang terjadi". Sedangkan menurut Sulistinah (2011:1) “di dalam proses pembelajaran sumber belajar sangat penting, sumber belajar utama adalah adanya buku sumber atau buku ajar". Sumber belajar yang penulis pergunakan untuk penyusunan bahan ajar tentang pemanfaatan lahan pada pokok bahasan pelestarian lingkungan hidup yaitu lingkungan alam di Kecamatan Argapura yang dimanfaatkan oleh masyarakat setempat 
sebagai lahan garapan dan buku IPS Geografi sebagai pendukung.

Tahap selanjutnya untuk pengembangan konsep bahan ajar yaitu menyusun peta bahan ajar. Penyusunan peta bahan ajar dilakukan setelah analisis kebutuhan bahan ajar. Berikut ini disajikan peta kebutuhan bahan ajar untuk satu kali pertemuan berkaitan dengan materi pemanfaatan lahan.

Penulis membuat bahan ajar tentang pemanfaatan lahan berupa CD interaktif. CD interkatif tersebut terdiri atas judul, petunjuk belajar, kompetensi dasar, materi pokok, informasi pendukung, latihan, tugas

Tabel 4.

Matriks Analisis Kurikulum IPS Geografi Pada Pokok Bahasan Pelestarian atau langkah kerja dan penilaian. Pembuatan konsep bahan ajar berbentuk CD interkatif dengan harapan bahan ajar akan lebih menarik perhatian peserta didik dibandingkan jika berbentuk cetak. Ketika bahan ajar menarik maka diharapkan peserta didik akan merasa tertarik untuk menyimak dan menyenangkan dalam proses pembelajaran sehingga materi pembelajaran akan lebih bermakna bagi siswa dan terhindar dari sifat verbalisme karena konsep bahan ajar berbentuk CD interaktif disertai gambar-gambar untuk lebih memudahkan peserta didik memahami materi.

\section{Lingkungan Hidup Kelas VIII semester I}

\begin{tabular}{|c|c|c|c|c|c|c|c|}
\hline \multirow{2}{*}{$\begin{array}{c}\text { Standar } \\
\text { Kompetensi }\end{array}$} & \multirow{2}{*}{$\begin{array}{l}\text { Kompetensi } \\
\text { Dasar }\end{array}$} & \multicolumn{2}{|c|}{ Indikator } & \multicolumn{2}{|c|}{ Materi Pokok } & \multirow{2}{*}{$\begin{array}{l}\text { Pengalam } \\
\text { an Belajar }\end{array}$} & \multirow{2}{*}{$\begin{array}{c}\text { Jenis } \\
\text { Bahan } \\
\text { Ajar }\end{array}$} \\
\hline & & Pada Silabus & Hasil Penelitian & Pada Silabus & $\begin{array}{c}\text { Hasil } \\
\text { Penelitian }\end{array}$ & & \\
\hline $\begin{array}{l}\text { Memahami } \\
\text { permasalaha } \\
\text { n sosial } \\
\text { berkaitan } \\
\text { dengan } \\
\text { pertumbuhan } \\
\text { jumlah } \\
\text { penduduk. }\end{array}$ & $\begin{array}{l}\text { Mendeskripsik } \\
\text { an } \\
\text { permasalahan } \\
\text { lingkungan } \\
\text { hidup dan } \\
\text { upaya } \\
\text { penanggulang } \\
\text { annya dalam } \\
\text { pembangunan } \\
\text { berkelanjutan }\end{array}$ & 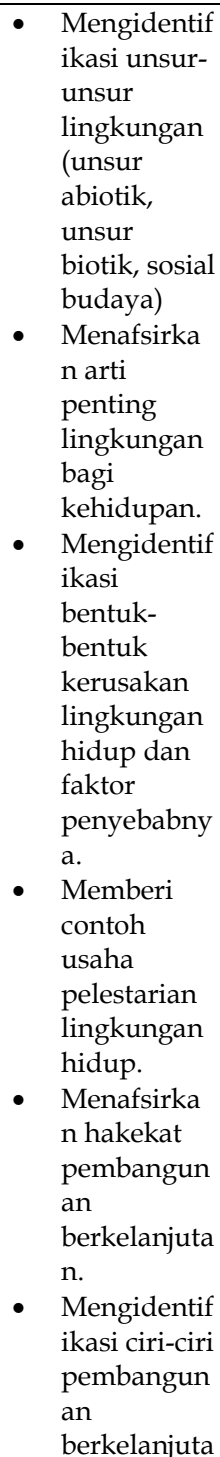 & $\begin{array}{l}\text { Mendeskripsi } \\
\text { kan definisi } \\
\text { lahan } \\
\text { Mengidentifik } \\
\text { asi komponen } \\
\text { lahan } \\
\text { Mengidentifik } \\
\text { asi bentuk- } \\
\text { bentuk } \\
\text { kerusakan } \\
\text { lingkungan } \\
\text { lahan dan } \\
\text { faktor } \\
\text { penyebabnya. } \\
\text { Mengidentifik } \\
\text { asi bentuk } \\
\text { pemanfaatan } \\
\text { yang sesuai } \\
\text { atau tidak } \\
\text { sesuai } \\
\text { Memberi } \\
\text { contoh upaya } \\
\text { penanggulang } \\
\text { an kerusakan } \\
\text { lahan. } \\
\text { Mengidentifik } \\
\text { asi peran } \\
\text { serta } \\
\text { masyarakat } \\
\text { dalam } \\
\text { mengelola } \\
\text { lingkungan } \\
\text { lahan. } \\
\text { - }\end{array}$ & $\begin{array}{l}\text { Mengidenti } \\
\text { fikasi } \\
\text { unsur- } \\
\text { unsur } \\
\text { lingkungan } \\
\text { (unsur } \\
\text { abiotik, } \\
\text { unsur } \\
\text { biotik, } \\
\text { sosial } \\
\text { budaya) } \\
\text { Menafsirka } \\
\text { n arti } \\
\text { penting } \\
\text { lingkungan } \\
\text { bagi } \\
\text { kehidupan. } \\
\text { Mengidenti } \\
\text { fikasi } \\
\text { bentuk- } \\
\text { bentuk } \\
\text { kerusakan } \\
\text { lingkungan } \\
\text { hidup dan } \\
\text { faktor } \\
\text { penyebabny } \\
\text { a. } \\
\text { fikasi ciri- } \\
\text { ciri } \\
\text { contoh } \\
\text { usaha } \\
\text { pelestarian } \\
\text { lingkungan } \\
\text { hidup. } \\
\text { nenafsirka } \\
\text { pemakekat } \\
\text { an } \\
\text { berkelanjut } \\
\text { an. } \\
\text { - }\end{array}$ & $\begin{array}{ll}\text { Definisi } \\
\text { Lahan } \\
\text { Komponen } \\
\text { Lahan } \\
\text { Bentuk- } \\
\text { bentuk } \\
\text { Kerusakan } \\
\text { Lingkungan } \\
\text { dan faktor } \\
\text { penyeba } \\
\text { Contoh } \\
\text { bentuk } \\
\text { pemanfaata } \\
\text { n lahan } \\
\text { yang sesuai } \\
\text { dengan } \\
\text { yang tidak } \\
\text { sesuai } \\
\text { Upaya } \\
\text { Penanggula } \\
\text { ngan } \\
\text { kerusakan } \\
\text { lahan } \\
\text { Peran serta } \\
\text { masyarakat } \\
\text { dalam } \\
\text { mengelola } \\
\text { lahan }\end{array}$ & $\begin{array}{l}\text { Menentu } \\
\text { kan } \\
\text { pemanfa } \\
\text { atan } \\
\text { lahan } \\
\text { yang } \\
\text { cocok } \\
\text { berdasar } \\
\text { kan } \\
\text { kemiring } \\
\text { an lereng }\end{array}$ & $\begin{array}{l}\text { CD } \\
\text { interaktif. }\end{array}$ \\
\hline
\end{tabular}




\begin{tabular}{lll}
\hline & & \\
\hline n. & pembangun \\
Mengidentif & an \\
ikasi & berkelanjut \\
penerapan & an. & Mengidenti \\
pembangun & fikasi \\
an & penerapan \\
berkelanjuta & pembangun \\
n. & an \\
& berkelanjut \\
& an. \\
\hline
\end{tabular}

Sumber: Silabus KTSp dan hasil penelitian 2013

\section{SIMPULAN}

Berdasarkan hasil analisis yang telah diuraikan pada bab $1 \mathrm{~V}$, maka dapat disimpulkan beberapa hal sebagai berikut : 1) Pemanfaatan lahan di Kecamatan Argapura sebagian besar tidak sesuai dengan kemiringan lerengnya. Di antara pemanfaatan lahan yang ada, pemanfaatan lahan ladang merupakan pemanfaatan lahan oleh masyarakat petani setempat yang mempunyai luas paling besar dengan kriteria tidak sesuai dibandingkan dengan pemanfaatan ladang yang sesuai; 2) FaktorFaktor penyebab pemanfaatan lahan oleh masyarakat petani setempat yaitu tingkat pendidikan, luas kepemilikan lahan, status kepemilikan lahan, frekuensi mmengikuti penyuluhan, dan tingkat pendapatan. Di antara semua faktor yang semula diduga mendukung ternyata hasil penelitian menyatakan bahwa semakin intensif petani mengikuti penyuluhan, semakin tidak meperhatikan kaidah pemanfaatan lahan sesuai kemiringan lereng. Hal tersebut disebabkan oleh materi penyuluhan hanya intensif untuk eksploitasi lahan tanpa memerhatikan kaidah pelestarian lingkungan hidup. Sehingga proses pendidikan terhadap peserta didik merupakan cara yang paling efektif untuk memberikan informasi tentang pemanfaatan lahan yang sesuai untuk bekal mereka kelak ketika terjun ke masyarakat; 3) Pemahaman peserta didik terhadap kondisi lahan tidak sejalan dengan sikap mereka terhadap pemanfaatan lahan. Pemahaman peserta didik tentang pemanfaatan lahan di daerah rawan bencana erosi maupun longsor bagus tetapi secara aplikasi di lapangan mereka sangat kurang. Sikap peserta didik ternyata tidak dipengaruhi atau tidak ada hubungannya dengan pemahaman mereka tentang pemanfaatan lahan. Hal ini diprediksi karena bahan ajar tidak kontekstual sehingga menimbulkan kesenjangan antara pemahaman terhadap kondisi lingkungan dengan sikap mereka terhadap pemanfaatan lahan; 4) Pengembangan bahan ajar IPS berkaitan dengan pemanfaatan lahan pada materi pelestarian lingkungan hidup dilakukan melalui tahaapan-tahapan yaitu: analisis kebutuhan bahan ajar, penyusunan peta bahan ajar, penyusunan bahan ajar berdasarkan struktur masing-masing. Pengembangan bahan ajar dalam penelitian ini dengan cara menambahkan indikator pembelajaran yang berkaitan dengan pemanfaatan lahan.

Berdasarkan kesimpulan di atas penulis mengajukan rekomendasi sebagai berikut : 1) Pemanfaatan lahan harus mengikuti kaidah dalam pengolahan lahan supaya kelestarian lingkungan tetap terjaga; 2) Perumusan bahan ajar selayaknya kontekstual dan Lingkungan sekitar seyogyanya dijadikan sebagai sumber belajar sehingga pemahaman peserta didik terhadap pemanfaatan lahan bisa diaplikasikan ke dalam kehidupan sehari-hari, artinya tidak hanya sebatas kognitif saja dan terhindar dari verbalisme. Berdasarkan pemikiran tersebut dirumuskanlah bahan ajar tentang pemanfaatan lahan. Rumusan bahan ajar dalam penelitian ini baru sampai tataran konsep dan belum diujicobakan kepada peserta didik, diharapkan untuk penelitian selanjutnya bisa diujicobakan. 


\section{DAFTAR PUSTAKA}

Bappeda. (2011). Rencana Detail Tata Ruang Kawasan Barat Gunung Ciremai Tahun Anggaran 2010. Majalengka : Bappeda.

Keputusan Menteri Kehutanan Nomor SK 424/Menhut-II/2004. Tentang Perubahan Fungsi Kawasan Hutan Lindung pada kelompok Hutan Gunung Ciremai Seluas $=15.500$ (Lima belas Ribu Lima Ratus) Hektar Terletak di Kabupaten Kuningan dan Majalengka, Provinsi Jawa Barat Menjadi Taman Nasional Gunung Ciremai.

Kurung dan Ginanjar, M. (2012). Restorasi Kawasan Taman Nasional Gunung Ciremai. Buletin Ciremai, Vol 02 No. 04. Kuningan: BTNGC.

Lasaiba. (2013). Kajian Keruangan Penggunaan Lahan Dalam Pengembangan Kota Ambon Berbasis Ekologi. Jurnal Pendidikan Geografi UNESA [Online], Vol 11, (21), 12 halaman. Tersedia: http://geografi.jurnal.unesa.ac.id/136_9 31/kajian-keruangan-penggunaanlahan--dalam-pengembangan-kotaambon-berbasis-ekologi [5 Agustus 2013]

Prastowo, A .(2012). Panduan Kreatif Membuat Bahan Ajar Inovatif, Menciptakan Metode Pembelajaran yang menarik dan Menyenangkan. Yogyakarta: Diva press.

Purnomo, N.H. (2013). Penyebab Dan Sebaran Longsor Lahan Di Kompleks
Gunungapi Kuarter Arjuno Jawa Timur. Jurnal Pendidikan Geografi UNESA [Online], Vol 11, (21), 10 halaman. Tersedia: http://geografi.jurnal.unesa. ac.id/136_932/penyebab-dan-sebaranlongsor-lahan-di-kompleks-gunungapikuarter-arjuno-jawa-timur $[5$ Agustus 2013]

Singarimbun, M. (1995). Metodologi Penelitian Survei. Yogyakarta: LP3ES

Sugiyono. (2008). Metode Penelitian Kuantitatif Kualitatif dan $R \quad \& \quad D$. Bandung: Alfabeta.

Sugiyono. (2009). Metode Penelitian Administrasi dilengkapi Metode $R$ \& D. Bandung: Alfabeta.

Sulistinah. (2011). Perkuliahan Biogeografi dengan Buku Ajar pada Mahasiswa S1 Jurusan Pendidikan Geografi Fakultas Ilmu Sosial Universitas Negeri Surabaya (Suatu Uji Coba). Jurnal Pendidikan Geografi UNESA [Online], Vol 10, (19), 10 halaman.Tersedia:http://geografi.jurnal. unesa.ac.id/121_815/perkuliahanbiogeografi-dengan-buku--ajar-padamahasiswa-s1-berbasis-ekologi[5

Agustus 2013]

Surakmad. (1982). Pengantar penelitian Ilmiah. Bandung : Tarsito 